\title{
INFLUENCE OF BOND BEHAVIOUR OF FLEXURAL GFRP REINFORCEMENT ON FAILURE MECHANISMS IN BEAMS WITHOUT STIRRUPS
}

\author{
M. KASZUBSKA ${ }^{1}$, R. KOTYNIA ${ }^{2}$
}

\begin{abstract}
The aim of the paper is to investigate the shear failure mechanisms in T-shape, single span and simply supported beams exclusively reinforced with longitudinal glass fiber reinforced polymer (GFRP) bars. Usually the critical shear crack in RC beams without stirrups develops through the theoretical compression strut reducing the shear strength following the shear failure. The main parameter affecting the crack pattern and the shear strength of the beams is the shear slenderness. However, the test results presented in the paper indicated the new arching effect due to the bond losing between the GFRP flexural reinforcement and concrete. This failure mode revealed unexpected critical crack pattern and failure mode. The research of concrete beams flexurally reinforced with GFRP bars without stirrups indicated two failure modes: typical shear-compression and a new one leading by the bond losing between the ordinary reinforcement and concrete.
\end{abstract}

Keywords: shear, GFRP reinforcement, bond behaviour

\section{INTRODUCTION}

Various key parameters that influence bond performance of FRP bars to concrete are different than in steel bars, so the bond behaviour of FRP bars to concrete is expected to vary from that of conventional steel reinforcement. The modulus of elasticity and the shear stiffness of FRP bars are lower than these of steel (particularly in the lateral and the longitudinal direction). Moreover, the FRP

\footnotetext{
${ }^{1}$ MSc., Eng., Lodz University of Technology, Faculty of Civil Engineering, Architecture and Environmental Engineering, al. Politechniki 6, 90-924 Łódź, Poland, e-mail: monika.dymecka@.p.lodz.pl

${ }^{2}$ Prof. PhD., Eng., Lodz University of Technology, Faculty of Civil Engineering, Architecture and Environmental Engineering, al. Politechniki 6,90-924 Łódź, Poland, e-mail: renata.kotynia@p.lodz.pl
} 
coefficient of thermal expansion is different from that of steel or concrete [3]. At the beginning of loading, the bond mechanism is governed by the chemical adhesion between reinforcement and concrete. As the load increases the adhesion breaks down, the principal tensile stress caused by bond stress reaches the tensile strength of concrete and microcracks initiate at the tips of the bar deformations, which allow the bar to slip. As the slip of the bar increases the bearing stress from the bar to the surrounding concrete increase considerably. At this stage the splitting resistance of the concrete surrounding the bar is decisive. If the bar is not adequately confined (for example in beams without stirrups) and the value of the tensile hoop stress exceeds the tensile strength of concrete, splitting cracks may develop along the length of the reinforcing bar.

The development of cracks in loaded beams is strictly related with the bond behaviour of reinforcement. In flexural member the tensile stress in the concrete surrounding the reinforcement is developed through the bond stress between concrete and reinforcement. The stress in the region adjacent to the crack are significantly released, so the cracks always developed at certain distance. Usually in RC beams tested in shear the cracks developed along the shear span and finally critical crack develops through the theoretical compression strut and disturbed the direct transfer the force to the support. The way of development of cracks through the inclined compression chord of beam is dependent on the shear slenderness a/d (a - shear span, $d$ - effective depth of the beam) [6]. However, the research conducted by Leonhardt and Walther [8] indicated another crucial effect deriving from the bond behaviour of the flexural reinforcement to concrete that influenced on the critical shear crack development. The beams investigated by Leonhardt and Walther were geometrically identical and had the shear span to depth ratio equal to 2.77. The beams EB1 with smooth bars reached the strength by $72 \%$ higher than the beams EA1 with deformed bars. This difference is due to the inclined crack in specimen EA1 develops through the theoretical compression strut, thus reducing its strength. The shape of the critical crack impact on contribution of the various shear-transfer actions (aggregate interlock effect, dowel action of the longitudinal reinforcement, the uncracked concrete in the compressive zone, and the direct strut action for point loads close to the support) [1]. In specimen EB1, thanks to the reduced bond strength, only a limited part of the inclined crack developed through the theoretical inclined strut, which significantly increased the strength of the member [10].

A similar phenomenon based on two different failure modes observed in an experimental research conducted on the T-section RC beams ( $b_{\text {eff }}=400 \mathrm{~mm}, b_{w}=150 \mathrm{~mm}, \mathrm{~h}_{\mathrm{f}}=60 \mathrm{~mm}, \mathrm{~h}_{\text {tot }}=400 \mathrm{~mm}$ ), single span and simply supported with a clear span of $1.8 \mathrm{~m}$, tested in three-point monotonic loading. The twelve GFRP reinforced beams presented in this paper belonged to the extensive research program consisted of two series of geometrically identical beams without stirrups with steel and 
GFRP bottom reinforcement. To investigate the effect of reinforcement ratio, number of bars per layer, number of layers and bar diameter on the shear capacity, three values of reinforcement ratio ( $\rho_{1}$ $\approx 1.0 \%, \approx 1.4 \%$, and $\approx 1.8 \%$ ) were adopted, with the corresponding bar's diameters of 12,16 , and 18 $\mathrm{mm}$. The second investigated parameter was the compressive concrete strength and its hardened composition. Primary the concrete of second series were designed with the compressive strength of $50 \mathrm{MPa}$. Unfortunately, some mistake was made in plant and the concrete compressive strength turned out much lower. Even though the concrete compressive strength in two beams' series was slightly different: $\mathrm{f}_{\mathrm{cm}}=31.7 \mathrm{MPa}$ in I series beams and $\mathrm{f}_{\mathrm{cm}}=35.9 \mathrm{MPa}$ in the II series, the hardened concrete composition was visually different. The aim of the investigation was to analyze the critical shear crack development failure modes and the ultimate loads in the beams of two corresponding series of beams, which failed by a typical shear-compression failure or due to bond losing of the flexural reinforcement to the concrete. For a deeper analysis of the cracking pattern during the failure process a digital measurement based on photogrammetry tools were involved to enable a detailed analysis of the failure process.

\section{THE EXPERIMENTAL PROGRAM}

To analyse was chosen the beams failed due to bond losing of the flexural reinforcement to the concrete and in shear-compression with the same configuration of bottom reinforcement (Table 1).

Table 1. Details of test specimens.

\begin{tabular}{|c|c|c|c|c|c|c|c|c|}
\hline Beams & Series & $\begin{array}{c}\mathrm{f}_{\mathrm{cm}} \\
{[\mathrm{MPa}]}\end{array}$ & $\begin{array}{c}\text { Number of } \\
\text { bars [-] }\end{array}$ & $\begin{array}{c}\text { Diameter } \\
\text { of bars } \\
{[\mathrm{mm}]}\end{array}$ & $\begin{array}{c}\mathrm{A} \\
{[\mathrm{mm} 2]}\end{array}$ & $\rho_{1}[\%]$ & $\mathrm{d}[\mathrm{mm}]$ & $\mathrm{a} / \mathrm{d}[-]$ \\
\hline G-512-35-15 & II & 36.02 & \multirow{4}{*}{5} & \multirow{4}{*}{12} & 565 & 0,99 & 379 & 2,90 \\
\hline G-512-30-15 & I & 30.20 & & & 565 & 0,99 & 379 & 2,90 \\
\hline G-512-35-35 & II & 34.95 & & & 565 & 1,05 & 359 & 3,06 \\
\hline G-512-30-35 & $\mathrm{I}$ & 28.80 & & & 565 & 1,05 & 359 & 3,06 \\
\hline G-318-35-35 & II & 34.95 & \multirow{4}{*}{3} & \multirow{4}{*}{18} & 763 & 1,43 & 356 & 3,09 \\
\hline G-318-30-15 & I & 28.80 & & & 763 & 1,35 & 376 & 2,93 \\
\hline G-318-35-15 & II & 37.05 & & & 763 & 1,35 & 376 & 2,93 \\
\hline G-318-30-35 & I & 30.50 & & & 763 & 1,43 & 356 & 3,09 \\
\hline G-418-35-15 & II & 35.00 & \multirow{4}{*}{4} & \multirow{4}{*}{18} & 1018 & 1,80 & 376 & 2,93 \\
\hline G-418-30-15 & I & 28.80 & & & 1018 & 1,80 & 376 & 2,93 \\
\hline G-418-35-35 & II & 35.00 & & & 1018 & 1,91 & 356 & 3,09 \\
\hline G-418-30-35 & I & 30.20 & & & 1018 & 1,91 & 356 & 3,09 \\
\hline
\end{tabular}

The beams did not include any shear reinforcement and were flexurally reinforced with GFRP bars. For the designation of the beams of the present experimental program the following acronym was 
adopted, G-X $\phi-Y-Z$, where $G$ means the flexural bars are of GFRP type, $\mathrm{X}$ is the number of bars of $\phi$ diameter (in $\mathrm{mm}$ ), $\mathrm{Y}$ represents the average compressive strength for the concrete and $\mathrm{Z}$ is the cover thickness. Since the bottom GFRP bars were straight, the proper anchored conditions were ensured by embedding the bars into a steel box filled with an epoxy resin.

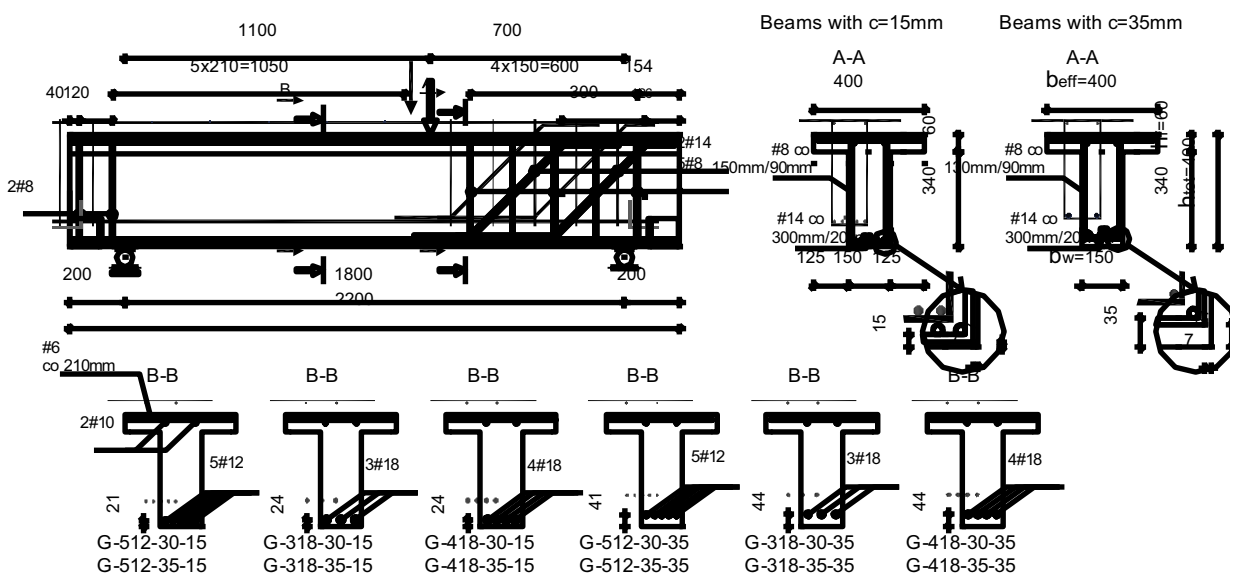

Fig. 1. The reinforcement in tested beams.

The top longitudinal reinforcement of all the beams consisted of two straight GFRP bars of $10 \mathrm{~mm}$ diameter, maintained in their aimed position by using transversal short steel bars of $6 \mathrm{~mm}$ diameter at $210 \mathrm{~mm}$ spacing, located in the flange (Fig.1). There were no stirrups in the largest shear span, while the shortest one was reinforced with closed steel stirrups of $8 \mathrm{~mm}$ diameter at $150 / 90 \mathrm{~mm}$ spacing in beams with thickness of concrete cover $15 \mathrm{~mm}$ and at $130 / 90 \mathrm{~mm}$ spacing in beams with thickness of concrete cover $35 \mathrm{~mm}$ and steel bent bars of $14 \mathrm{~mm}$ diameter. The beams were simply supported on two steel supports with the movable (rotation and beam's axial displacement free movements) one in the monitored shear span, and the other with only free rotation movement (Fig. 2). The load was applied under displacement control at $10 \mu \mathrm{m} / \mathrm{s}$ by using $\mathrm{T}$ cross section steel profile to distribute the applied load along the width of the flange (contacted area $10 \mathrm{~mm} \times 400 \mathrm{~mm}$ ). Vertical displacements were registered by eight LVDTs of $20 \mathrm{~mm}$ stroke and $0.1 \mathrm{~mm}$ accuracy (number 22 to 29) mounted on an independent steel frame (Fig. 2). The digital image correlation system was used to provide complementary information to the displacement measurements from LVDTs, and to help on the interpretation of the cracking process of the tested beams. The information from DIC is obtained by comparing digital photographs of a component or test piece at different stages of 
deformation. By tracking blocks of pixels, the system can measure surface displacement and build up the full $2 \mathrm{D}$ and $3 \mathrm{D}$ deformation vector fields and maps of concrete strain. The photogrammetric technique used in this research was prepared for 3D measurements using two cameras with a focal length of $50 \mathrm{~mm}$ and a resolution of 4 megapixels. The registered area of concrete was indicated by a square at dashed line in Figure 4. Pictures were taken at $1 \mathrm{~Hz}$ frequency, while images were analysed using the VIC3D software.

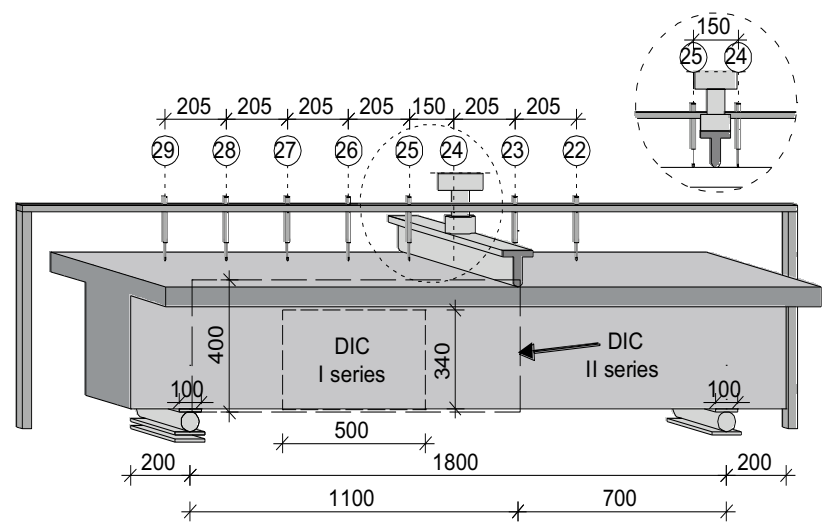

Fig. 2. Static scheme, LVDT arrangement and the area monitored by DIC

The relevant tensile properties of the adopted GFRP bars with single braid ribs were determined from experimental tests carried out with 15 specimens according to ISO Standard 10406-1 [5]. The average modulus of elasticity and the tensile strength registered in the tests were $50.5 \mathrm{GPa}(\mathrm{COV}=1.6 \%)$ and $1091 \mathrm{MPa}(\mathrm{COV}=10.7 \%)$, respectively. The compressive strength along the fibres declared by the producer was adopted as not lower than $350 \mathrm{MPa}$. The spacing ribs of bars ranged from $6.8 \mathrm{~mm}$ to $8.5 \mathrm{~mm}$ for $18 \mathrm{~mm}$ bar diameter and from $7.5 \mathrm{~mm}$ to $9.6 \mathrm{~mm}$ for $12 \mathrm{~mm}$ bar diameter. The strength properties of concrete were determined according to EN 206-1 standard [4]. The average cylinder concrete compressive strength $\mathrm{f}_{\mathrm{cm}}$ in the first series (obtained on 15 specimens) was $31.7 \mathrm{MPa}$ $(\mathrm{COV}=8 \%)$, the average modulus of elasticity $\mathrm{E}_{\mathrm{cm}}$ was $26.7 \mathrm{GPa}(\mathrm{COV}=6 \%)$, while the average splitting tensile strength $\mathrm{f}_{\mathrm{ct}}$ was $2.9 \mathrm{MPa}(\mathrm{COV}=8 \%)$. In the second series: $\mathrm{f}_{\mathrm{cm}}=35.9 \mathrm{MPa}(11$ specimens, $\mathrm{COV}=4 \%), \mathrm{E}_{\mathrm{cm}}=25.8 \mathrm{GPa}(\mathrm{COV}=3 \%)$ and $\mathrm{f}_{\mathrm{ct}}=3.4 \mathrm{MPa}(\mathrm{COV}=7 \%)$. Even though a difference in the concrete strength was not big the composition of hardened concrete in both series was significantly different. In the II series there were more there were more small aggregate fractions. The concrete looked like more sand ware used. A proper assessment and interpretation of the 
differences in the concrete composition of both series was not possible because the concrete supplier did not provide the recipe and composition of the concrete. As suggested in [3] for concrete compressive strengths greater than $30 \mathrm{MPa}$, the bond failure interfaces occur in the surface of an FRP bar, but in presented beams, which failed with bond loss, the reinforcement was not damaged, so bond failure had to be in concrete (Fig. 3). This confirmed that despite the higher compressive strength the concrete of second series had worse quality.

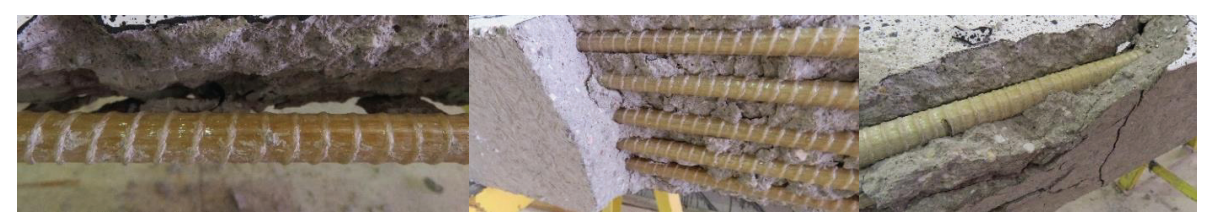

Fig. 3. The outcrop of bottom reinforcement in beams G-512-35-15, G-512-35-35 and G-418-35-15

\section{TEST RESULTS}

The main results are presented in Table 2. In order to take into account, the different flexural reinforcement depth on the shear capacity of the beam, the concept of average shear stress $\left(\tau=V /\left(b_{w} d\right)\right.$, where $\mathrm{V}$ is the shear force in the monitored span and $b_{w}=150 \mathrm{~mm}$ is the width of the beam's web) was adopted. The authors distinguished two types of failure of tested beams: bond failure (B) and shear-compression failure (SC), which will be describe later on (Tab.2).

Table 2. Test results

\begin{tabular}{|c|c|c|c|c|}
\hline Beams & $\mathrm{V}_{\max }[\mathrm{kN}]$ & $\tau_{\max }[\mathrm{MPa}]$ & $\delta_{\mathrm{Fmax}}[\mathrm{mm}]$ & Failure mode \\
\hline G-512-35-15* & 29.66 & 0.52 & 0.8 & $\mathrm{~B}$ \\
\hline G-512-30-15 & 34.27 & 0.60 & 4.9 & $\mathrm{SC}$ \\
\hline G-512-35-35 & 60.27 & 1.12 & 10.4 & $\mathrm{~B}$ \\
\hline G-512-30-35 & 32.47 & 0.60 & 3.5 & $\mathrm{SC}$ \\
\hline G-318-35-35 & 46.04 & 0.86 & 4.9 & B \\
\hline G-318-30-15 & 38.57 & 0.68 & 2.6 & $\mathrm{SC}$ \\
\hline G-318-35-15 & 33.76 & 0.60 & 3.2 & $\mathrm{SC}$ \\
\hline G-318-30-35 & 34.42 & 0.64 & 2.6 & $\mathrm{SC}$ \\
\hline G-418-35-15 & 50.03 & 0.89 & 7.2 & $\mathrm{~B}$ \\
\hline G-418-30-15 & 38.14 & 0.68 & 2.4 & $\mathrm{SC}$ \\
\hline G-418-35-35 & 35.14 & 0.66 & 2.1 & $\mathrm{SC}$ \\
\hline G-418-30-35 & 39.41 & 0.74 & 2.6 & $\mathrm{SC}$ \\
\hline
\end{tabular}

Two beams in the series II, which failed in shear-compression, reached the lower shear capacity in relation to the analogous beams in the series $\mathrm{I}\left(\mathrm{f}_{\mathrm{cm}}=31.7 \mathrm{MPa}\right)$, even expected capacity should be 
slightly higher due to the higher compressive concrete strength (Tab. 2). Probably the decrease in the shear strength was caused by a reduction of the aggregate action due to smaller aggregate size. Figure 4 shows the comparison of capacity obtained in elements with a bond failure mode (black bars charts) with analogous elements failed in shear-compression (grey bar charts). The capacity beams failed in shear-compression was by $46 \%$ for $\rho_{1} \sim 1 \%$, from $21 \%$ to $31 \%$ for $\rho_{1} \sim 1,4 \%$ and from $17 \%$ to $26 \%$ for $\rho_{\mathrm{l}} \sim 1.8 \%$ lower than the corresponding elements with bond failure. The biggest difference in the capacity was gained for the lowest reinforcement ratio ( $\left.\rho_{1} \sim 1 \%\right)$, where the theoretical compression strut was the latest exposed to the critical diagonal shear crack (compare Fig. 6).

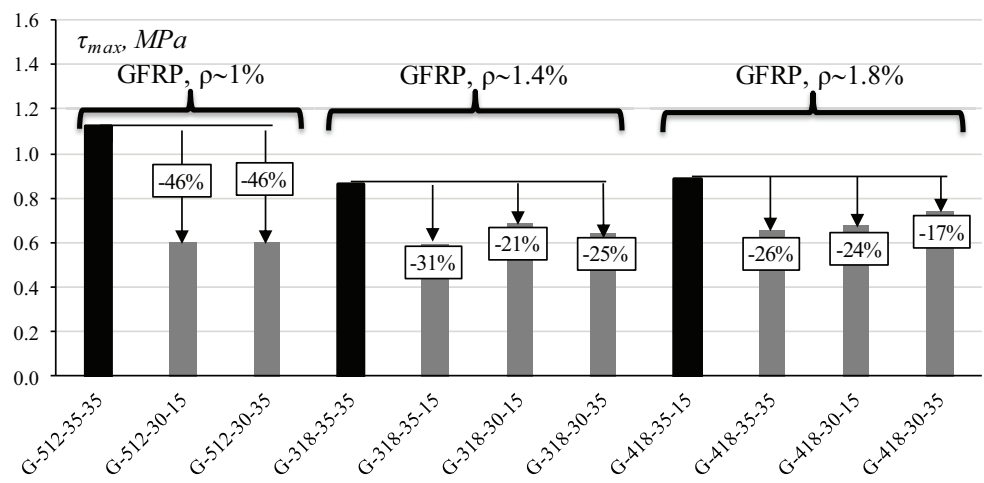

Fig. 4. The comparison of the capacity of tested beams
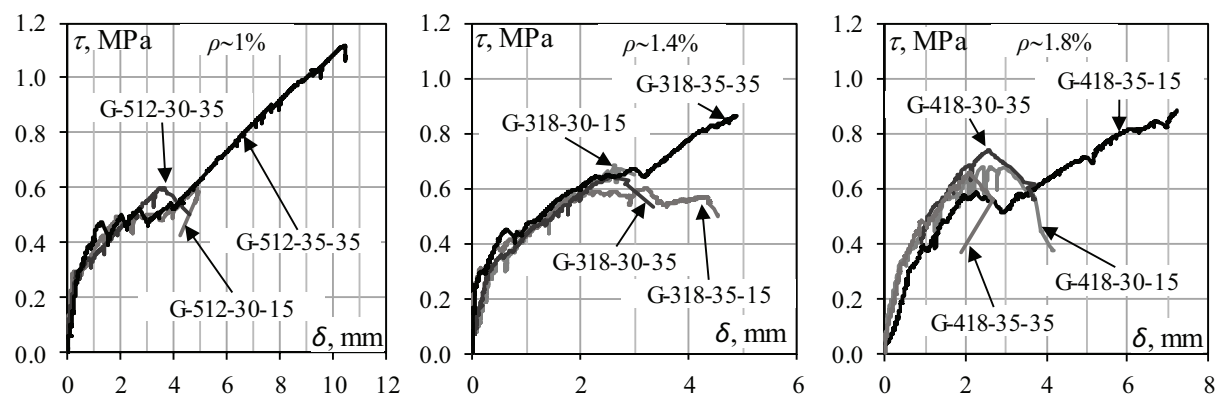

Fig. 5. The average deflection in tested beams

The shear stress charts in function of mean vertical displacement $(\tau-\delta)$ registered by LVDTs No. 24 and 25 are presented in Fig. 5. The beams G-512-35-35, G-418-35-15 and G-318-35-35 (with the arching action) failed due to the bond losing indicate a similar bi-linear behavior to the corresponding beams failed due to the shear-compression way. However, after a limit of the shear strength in the beams failed in shear-compression, the arching action caused the further shear stress increase almost 
linear until failure. The higher capacity of these three beams led to an increase in the deflection at the ultimate load. The significant increase in the average deflection $\delta_{\text {Fmax }}$ was observed in the beams with the reinforcement ratio $\rho_{\mathrm{l}} \sim 1 \%$ and $\rho_{\mathrm{l}} \sim 1.8 \%$ (114-201\% and 200-326\%, respectively, Table 2).

In almost all beams the first flexural cracks occurred in the beam mid-span. Then, during the load increasing flexural cracks developed and a diagonal crack appeared in the shear region. In all six beams of series I and only two from six beam of series II the failure progressed gradually from flexure to shear that was typical shear-compression failure [9], [2]. Contrary to expectations in four from six beams of series II, bond loosing between the flexural reinforcement and concrete occurred. It was never observed in the previous tests of beams included in presented research program. The cracking pattern in these four beams was different than in the rest of beams failed due to general shearcompression (Fig. 6-8). These beams reached much higher the maximum shear force $\mathrm{V}_{\max }$ comparing to the corresponding beams from series I and II (Table 2). The primary flexural cracks appeared close to the loaded section (in the bending moment region) in the beams, which failed due to shearcompression (G-512-30-15, G-512-35-35, G-512-30-35, G-318-30-15, G-318-35-15, G-318-30-35, G-418-30-15, G-418-30-35, G-418-35-35). By the load increasing the secondary cracks formed between the previous ones, in the zone close to the flexural reinforcement, as a consequence of the bond stress transfer between this reinforcement and surrounding concrete. Then the inclined crack propagated towards the flexural cracks, finally forming the critical shear crack (Fig. 6-8). Development of one of these critical shear cracks into the shear failure crack was governed by two mechanisms in the extremities of this crack: in the top extremity the crack progressed to the load point due to the relatively high influence of both shear and bending moment in this region; in the bottom extremity, the shear failure crack progressed along the interface between flexural reinforcement and surrounding concrete. When the primary flexural crack reached the compression chord, its inclination became almost flat progressing into the web-flange interface of the T-cross section. Finally, this crack propagated to the loading zone with a higher inclination, crossing the whole flange [7]. The critical shear crack in beams failed in shear-compression developed through the theoretical inclined compression strut of beam and interrupted a direct transfer of the shear force to the support. In this case the shear force was mainly transferred by an elbow-shaped strut and straight strut that develops do to the aggregate interlock action in the critical shear crack [10]. A development of an elbow-shaped strut deviated the compression strut leading to avoid the shear cracks propagation. This new shear-carrying mechanism (due to the arching action) depends on the crack pattern and the aggregate size that was smaller in the beams of series II comparing to the beams of series I. Completely different failure occurred in four beams of series II (G-512-35-15, G-512-35- 
35, G-418-35-15 and G-318-35-35), proceeded by an unexpected crack pattern comparing to the previous beams failed due to shear-compression (SC).
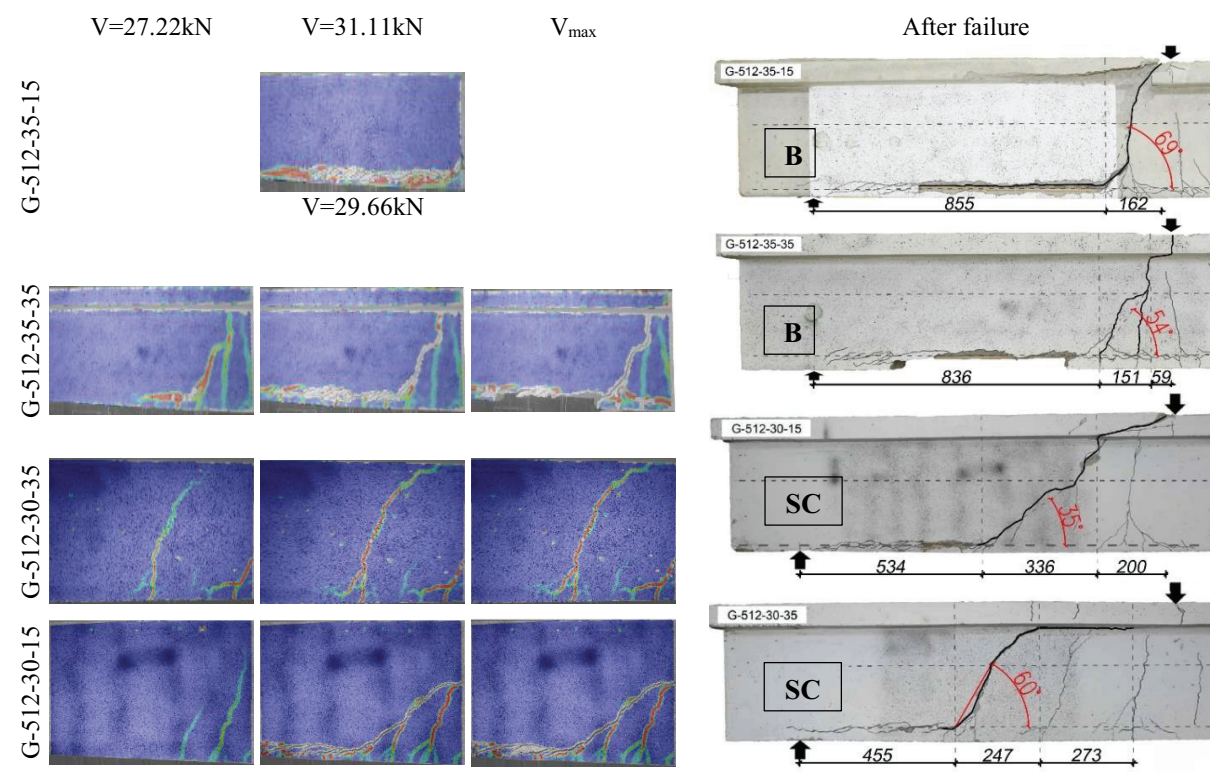

Fig. 6. The development of cracks and cracks pattern in beams with reinforcement ratio $\sim 1 \%$

$\mathrm{V}=27.22 \mathrm{kN}$

$\mathrm{V}=31.11 \mathrm{kN}$

$\mathrm{V}_{\max }$

After failure
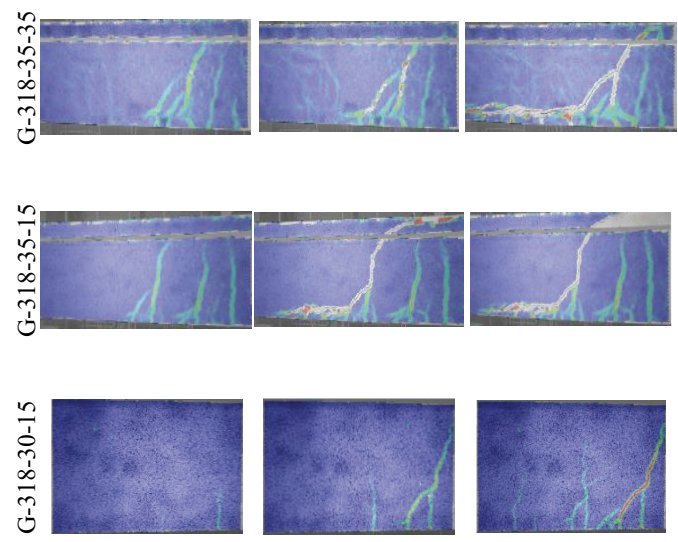


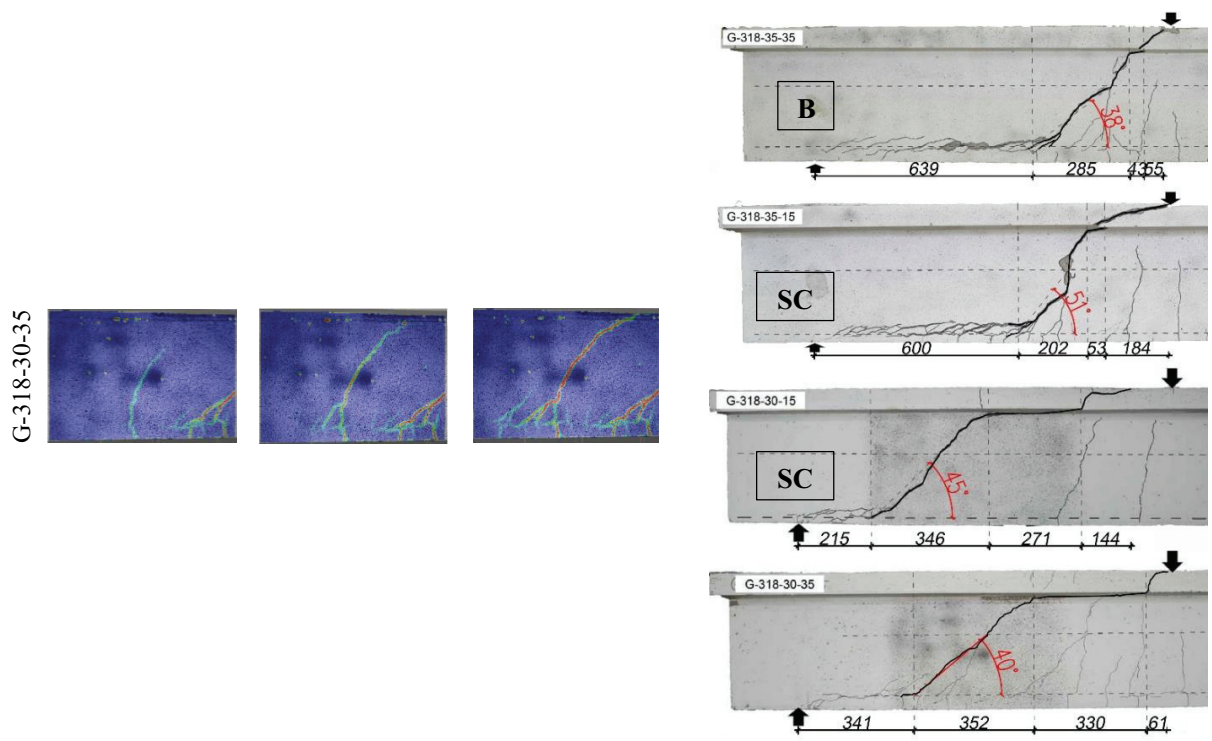

Fig. 7. The development of cracks and cracks pattern in beams with reinforcement ratio $\sim 1.4 \%$

In two beams of the series II $\left(f_{\mathrm{cm}}=35.9 \mathrm{MPa}\right)$ there were a clear bond loss of the GFRP bars to the concrete with clearly visible detachment of the bottom concrete cover. Under initial loading of the beam G-512-35-15 the typical flexural cracks appeared close to the point load. Then the primary crack developed in a horizontal direction at the level of the bottom reinforcement leading the bond losing of the bottom bars to the concrete along to the flexural GFRP reinforcement (Fig. 6). Due to concerns about this new failure mode (never observed in the previous beams) and concerns about damage of the installed LVDT gauges, the test was stopped at the level of load $29.66 \mathrm{kN}$ without reaching a typical failure mode or decrease in the load.

$\mathrm{V}=27.22 \mathrm{kN}$

$\mathrm{V}=31.11 \mathrm{kN}$

$\mathrm{V}_{\max }$

After failure
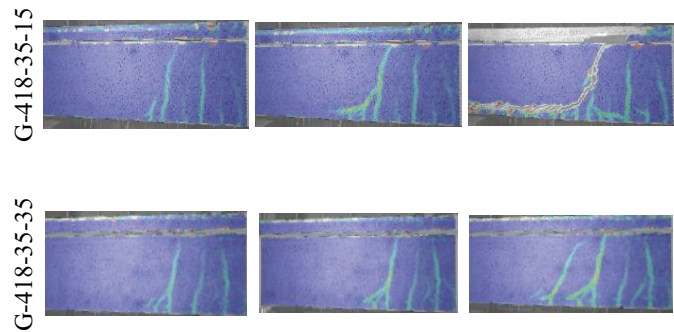


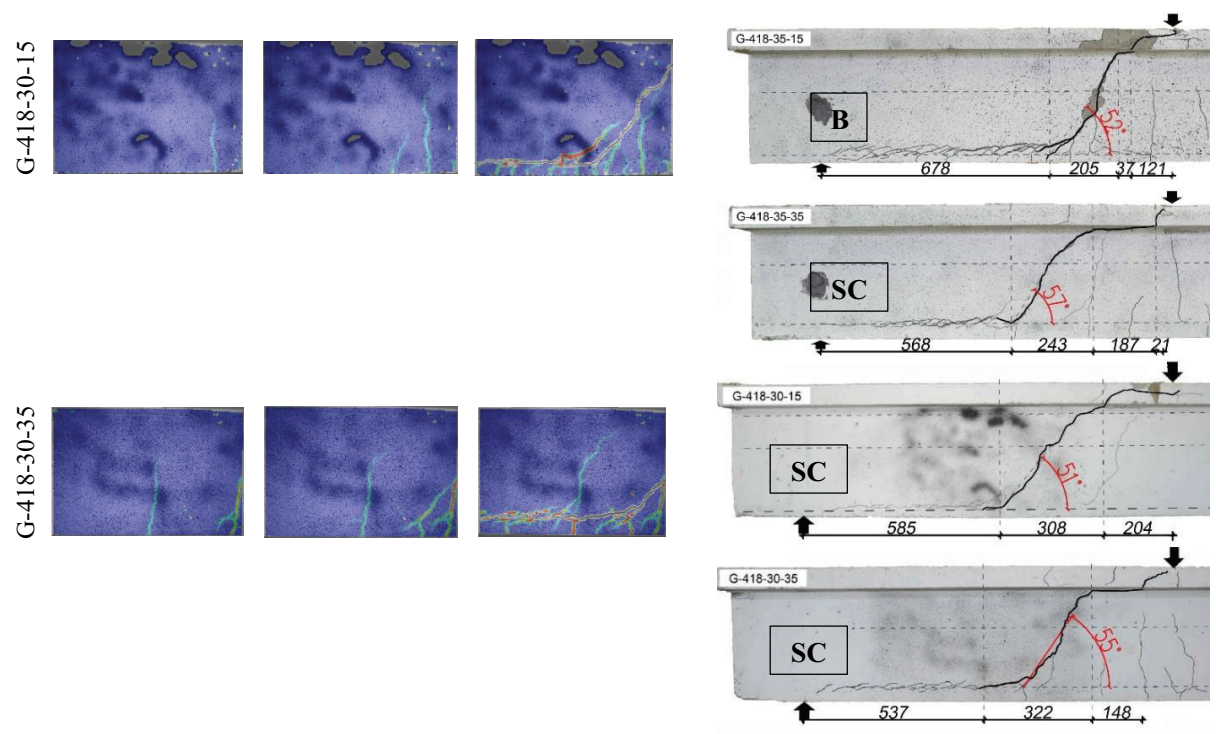

Fig. 8. The development of cracks and cracks pattern in beams with reinforcement ratio $\sim 1.8 \%$

The similar crack pattern was recorded in the beam G-512-35-35, but an experience of the previous beam G-512-35-15 encouraged to continue the test until failure. The beam G-512-35-35 cracked initially in flexure and then the only one vertical crack and one diagonal crack appeared in the tested shear span. Similar to the previous beam the horizontal crack appeared also along the bottom reinforcement and led to the detachment of concrete cover. The critical crack formed from the vertical one and other cracks with a small inclination appeared near the load point (Fig. 6). The short horizontal distance of crack appeared at the interface between the web and the flange, then the crack developed into the vertical crossing the flange under the point load. In the presented four beams due to development of the crack along the flexural reinforcement, the bond loosing of the GFRP bars to the concrete occurred limiting inclined crack development through the theoretical inclined strut, that allowed direct transfer of force to the support, that was observed in $\mathrm{RC}$ beams reinforced with steel [10].

\section{Conclusions}

The paper presents test results of T-section, GFRP flexurally reinforced beams without stirrups that revealed two failure modes: typical shear-compression failure and bond losing between GFRP bars and concrete. The experimental tests indicated, that the capacity of tested beams was highly 
dependent on a shape and location of the critical shear crack. The concrete composed of smaller aggregate (in the beams of series II) caused bond loosing between GFRP bars and concrete leading to a very limited inclined crack developed through the theoretical inclined strut and highly exposed arching action, which significantly increased the strength of the beams. The beams failed due to the bond losing indicated similar shear stress-deflection relationship until the shear stress corresponding to the shear-compression failure and then further linear increase in the stiffness conforming linear activation of the GFRP flexural reinforcement.

\section{ACKNOWLEDGEMENT}

The authors gratefully acknowledge the ComRebars Company who supplied the GFRP reinforcement for the experimental test.

\section{REFERENCES}

1. S. Campana, M. Fernández Ruiz, A. Anastasi, A. Muttoni, ,Analysis of shear-transfer actions on one-way RC members based on measured cracking pattern and failure kinematics", Magazine of Concrete Research 65(6): 386-404, 2013.

2. F. Cavagnis, M. Fernández Ruiz, A. Muttoni, „Shear failures in reinforced concrete members without transverse reinforcement: An analysis of the critical shear crack development on the basis of test results", Engineering Structures 103: 157-173, 2015.

3. CEB-fib, ,Bond of reinforcement in concrete. Bulletin 10”, 2000.

4. European Committee for Standardization (CEN), EN 206 2013. Concrete - Specification, performance, production and conformity, 2013.

5. International Organization for Standardization (ISO), „10406-1. Fibre-reinforced polymer (FRP) reinforcement of concrete Test methods Part 1: FRP bars and grids", 2015.

6. G. Kani, „The Riddle of Shear Failure and its Solution”, ACI Journal Proceedings 61(4): 441-468, 1964.

7. M. Kaszubska, R. Kotynia, J. A. O. Barros, H. Baghi, ,Shear behavior of concrete beams reinforced exclusively with longitudinal glass fiber reinforced polymer bars: Experimental research", Structural Concrete 19(1): 152161,2017

8. F. Leonhardt, R. Walther, "Shear Tests on Beams With and Without Shear Reinforcement”, Deutscher Ausschuss für Stahlbeton 151: 1-83, 1962.

9. A. Marí, J. Bairán, A. Cladera, E. Oller, C. Ribas, „Shear-flexural strength mechanical model for the design and assessment of reinforced concrete beams", Structure and Infrastructure Engineering 11: 1399-1419, 2015.

10. A. Muttoni i M. F. Ruiz, „Shear strength of members without transverse reinforcement as function of critical shear crack width", ACI Structural Journal 105(2): 163-172, 2008. 


\section{LIST OF FIGURES AND TABLES:}

Fig. 1. The outcrop of bottom reinforcement in beams G-512-35-15, G-512-35-35 and G-418-35-15

Rys. 1. Odkrywka zbrojenia dolnego w belkach G-512-35-15, G-512-35-35 i G-418-35-15

Fig.2. The reinforcement in tested beams.

Rys. 2. Zbrojenie badanych belek

Fig.3. Static scheme and LVDT arrangement.

Rys. 3. Schemat statyczny i rozmieszczenie czujników LVDT

Fig. 4. The area monitored by DIC

Rys. 4. Obszar monitorowany systemem DIC

Fig. 5. The comparison of the capacity of tested beams

Rys. 5. Porównanie nośności badanych belek

Fig. 6. The average deflection in tested beams

Rys. 6. Średnie ugięcie badanych belek

Fig. 7. The development of cracks and cracks pattern in beams with reinforcement ratio $\sim 1 \%$

Rys. 7. Rozwój rys i zarysowanie w belkach ze stopniem zbrojenia $\sim 1 \%$

Fig. 8. The development of cracks and cracks pattern in beams with reinforcement ratio $\sim 1.4 \%$

Rys. 8. Rozwój rys i zarysowanie w belkach ze stopniem zbrojenia $\sim 1.4 \%$

Fig. 9. The development of cracks and cracks pattern in beams with reinforcement ratio $\sim 1.8 \%$

Rys. 9. Rozwój rys i zarysowanie w belkach ze stopniem zbrojenia $\sim 1.8 \%$

Tab. 1. Details of test specimens

Tab. 1. Szczegóły badanych elementów

Tab. 2. Test results

Tab. 2. Wyniki badań 


\section{WPLYW PRZYCZEPNOŚCI ZBROJENIA PODŁUŻNEGO GFRP NA MECHANIZMY NISZCZENIA BELEK BEZ STRZEMION}

Keywords: ścinanie, GFRP, przyczepność

\section{STRESZCZENIE:}

Zjawisko przyczepności zapewnia w zginanych elementach żelbetowych na przekazanie naprężeń rozciągających z betonu na zbrojenie podłużne. Powstanie rysy powoduje obniżenie naprężeń rozciągających w jej bliskim sąsiedztwie, stąd pojawienie się kolejnej rysy możliwe jest tylko w pewnej odległości od rysy już istniejącej (zj. angielskiego ,primary crack”). Zwykle w elementach zginanych bez zbrojenia poprzecznego na odcinku ścinania, rysy ukośne rozwijają się w miarę wzrostu obciążenia wzdłuż całej długości odcinka ścinania, a w końcowym etapie ukośna rysa niszcząca rozwija się wzdłuż teoretycznego krzyżulca ściskanego i zaburza bezpośrednie przekazywanie siły ściskającej na podporę. Podstawowym parametrem wpływającym na sposób rozwoju tej rysy poprzez teoretyczny krzyżulec ściskany jest smukłość ścinania (a/d). Badania Leonhardta i Walthera prowadzone na belkach ze zbrojeniem gładkim wykazały istotny wpływ przyczepności zbrojenia podłużnego do betonu na położenie rysy krytycznej oraz na ostateczny mechanizm niszczenia (nietypowy dla elementów żelbetowych z podłużnym zbrojeniem żebrowanym o dobrej przyczepności do betonu). Leonhardt i Walther badali belki o smukłości ścinania 2,77, o tym samym przekroju i stopniu zbrojenia na zginanie, bez zbrojenia poprzecznego, różniące się jedynie typem podłużnego zbrojenia stalowego. Belki zbrojone prętami gładkimi uzyskały zaskakująco wysoką nośność na ścinanie (o 72\% wyższą) niż belki ze zbrojeniem żebrowanym. Wyjaśnienie tej różnicy w nośności i zarysowaniu obu belek należy upatrywać w rozwoju rysy krytycznej, która w belkach ze zbrojeniem żebrowanym przecięła teoretyczny krzyżulec ściskany, zmniejszając tym samym zdolność bezpośredniego przekazania siły na podporę. Natomiast w elemencie zbrojonym stalą gładką, na krótko po zarysowaniu na zginanie, doszło do utraty przyczepności zbrojenia podłużnego do betonu. W ten sposób po utracie przyczepności całego zbrojenia rozciąganego dobrze zakotwionego na podporach ukształtował się belce mechanizm łukowo -ściągowy. Wyniki badań Leonhardta i Walthera zainspirowały autorki do podobnej analizy wpływu przyczepności w prezentowanych w pracy badaniach własnych. Przedstawione elementy były częścią szerszego programu badawczego, jednak do niniejszej analizy wybrano jedynie 12 elementów o przekroju teowym $\left(b_{e f f}=400 \mathrm{~mm}, b_{w}=150 \mathrm{~mm}, h_{f}=60 \mathrm{~mm}\right.$, $h_{\text {tot }}=400 \mathrm{~mm}$ ) i rozpiętości w osiach podpór $1800 \mathrm{~mm}$, które uległy zniszczeniu ścinająco-ściskającemu oraz zniszczeniu związanemu z utratą przyczepności. Belki obciążano siłą skupioną położoną w odległości $1100 \mathrm{~mm}$ od osi podpory, co przekładało się na smukłość ścinania od 2,90 do 3,09 (w zależności od wysokości użytecznej zmiennej z uwagi na położenie zbrojenia podłużnego). Główne zbrojenie wykonano z prostych odcinków prętów GFRP o średnicach $12 \mathrm{~mm}$ i $18 \mathrm{~mm}$. Wszystkie pręty zakotwiono w stalowych skrzynkach wypełnionych zaprawą klejową. Zbrojenie górne stanowiły dwa pręty GFRP o średnicy $10 \mathrm{~mm}$ połączone krótkimi poprzecznymi prętami o średnicy $6 \mathrm{~mm}$, ułożonymi w półce przekroju teowego w rozstawie $210 \mathrm{~mm}$. Przeciwległą strefę przypodporową belki zabezpieczono przed zniszczeniem na ścinanie poprzez zastosowanie silnego zbrojenia poprzecznego, które stanowiły stalowe strzemiona $\mathrm{z}$ prętów o średnicy $8 \mathrm{~mm}$ oraz stalowe pręty odgięte o średnicy $14 \mathrm{~mm}$. Dla łatwej identyfikacji elementów przyjęto jednolity sposób opisu belek: G-X $\phi-Y-Z$, gdzie G oznacza zbrojenie GFRP, $X$ - liczbę prętów o średnicy $\varnothing$, Y planowaną wytrzymałość betonu na ściskanie na próbkach kostkowych w przypadku I serii (30MPa) oraz średnią uzyskaną wytrzymałość na ściskanie na próbkach walcowych w serii II (35 MPa), Z - grubość otuliny betonowej. Moduł sprężystości prętów GFRP wynosił $50.5 \mathrm{GPa}$, a średnia wytrzymałość na rozciąganie $1091 \mathrm{MPa}$. Belki oparto na przegubowych podporach, z których jedna, położona po stronie analizowanego odcinka ścinania była przesuwna. 
Obciążenie przekazywano przez stalowy trawers na całej szerokości półki w sposób ciągły, przy użyciu siłownika o zakresie $200 \mathrm{kN}$, sterowanego przemieszczeniem z prędkością $10 \mu \mathrm{m} / \mathrm{s}$. Pionowe przemieszczenia belek rejestrowano przy użyciu ośmiu czujników indukcyjnych zamocowanych do niezależnej stalowej ramy. Zachowanie belek pod obciążeniem monitorowano za pomocą systemu cyfrowej korelacji obrazu („digital image correlation” - DIC - ARAMIS), który rejestrował deformacje powierzchni belek (na przeciwległej stronie środnika). Proces obciążania elementów rejestrowano z prędkością 1 klatka na sekundę.

Pierwotnie zaplanowano dwie serie badawcze, które miały znacznie różnić się wytrzymałością betonu na ściskanie. Jednak błąd wytwórni betonu spowodował, że beton II serii charakteryzował się wytrzymałością na ściskanie zbliżoną do serii I $f_{c m}=35.9 \mathrm{MPa}$ (w serii I $f_{c m}=31.7 \mathrm{MPa}$ ). Ponadto struktura stwardniałego betonu serii II sugerowała większą zawartość kruszywa o małych średnicach (była bardziej ,piaszczysta”). Mimo nieznacznie wyższej wytrzymałości betonu na ściskanie elementy II serii, które uległy typowemu zniszczeniu na ścinanie (ścinająco-ściskającemu), uzyskały niższą nośność na ścinanie w porównaniu z analogicznymi belkami I serii. Niższa nośność na ścinanie belek II serii potwierdza wpływ bardziej „piaskowej” struktury stwardniałego betonu i może świadczyć o gorszych warunkach przyczepności zbrojeniem do betonu. To decyduje również o zmniejszeniu efektu zazębiania się kruszywa w nośności na ścianie.

Zniszczenie związane z utratą przyczepności zbrojenia głównego zaobserwowano w czterech elementach II serii: G-51235-15, G-512-35-35, G-418-35-15 oraz G-318-35-35, przy czym element G-512-35-15 został wyłączony z analizy z uwagi na przerwanie badania na skutek bardzo dużych przemieszczeń pionowych. Naprężenie ścinające uzyskane w belkach, które uległy zniszczeniu ścinająco-ściskającemu były o $46 \%$ niższe dla elementów o stopniu zbrojenia $\rho_{1} \sim 1 \%$, od $21 \%$ do $31 \%$ niższe dla $\rho_{\mathrm{l}} \sim 1.4 \%$ oraz od $17 \%$ do $26 \%$ niższe dla $\rho_{\mathrm{l}} \sim 1.8 \%$ w porównaniu odpowiadającymi elementami, które uległy zniszczeniu na skutek utraty przyczepności zbrojenia głównego, w których powstał mechanizm łukowościągowy. Do poziomu naprężeń niszczących uzyskanych w elementach, w których rysa krytyczna zaburzyła bezpośrednie przekazywanie siły na podporę, zależność naprężenie-ugięcie elementów G-512-35-35, G-418-35-15, G318-35-35 była zbliżona. Jednak po przekroczeniu tego poziomu następował wzrost sztywności belek i zależność $\tau-\delta$ była liniowa aż do zniszczenia. Wzrost nośności na ścinanie przyczynił się również do znacznego zwiększenia średniego ugięcia odpowiadającego sile maksymalnej w elementach zniszczonych na skutek utraty przyczepności (114-201\% dla $\rho_{1} \sim 1 \%$ oraz $200-326 \%$ dla $\rho_{1} \sim 1.8 \%$ ). Sposób zarysowania elementów, w których doszło do wykształcenia mechanizmu łukowo-ściągowego wykazywał pewne różnice w stosunku do pozostałych belek. W elementach, które uległy zniszczeniu ścinająco-ściskającemu najpierw pojawiały się rysy typowe dla zginania, w środkowej części belki pod siłą obciążającą. Wraz ze wzrostem obciążenia rysy te rozwijały się głównie w kierunku odcinka ścinania bez zbrojenia poprzecznego. Kierunek rysy niszczącej w badanych elementach na wysokości zbrojenia dolnego oraz w miejscu osiągnięcia poziomu półki ulegał zmianie na poziomy. Wraz ze wzrostem obciążenia zarysowaniu ulegała także półka przekroju teowego. W początkowym stadium obciążania elementu G-512-35-35 również powstały rysy typowe dla zginania, jak w elementach poprzednich, jednak w tym wypadku rysy ukośne rozwijały się głównie na obszarze poprzecznie zbrojonym. Natomiast na odcinku bez zbrojenia na ścinanie pojawiła się rysa pozioma wzdłuż zbrojenia, która spowodowała odspojenie otuliny. Rysa niszcząca powstała z połączenia rysy ukośnej położonej w niewielkiej odległości od punktu obciążenia z rysą niemal pionową. Na wysokości półki wystąpił krótki, poziomy odcinek rysy, który rozwinął się na półce w kierunku pionowym dokładnie pod siłą. W elementach G-418-35-15 oraz G-318-35-35 sposób rozwoju rys był zbliżony do elementów zniszczonych w sposób ścinająco-ściskający, jednak rysa niszcząca była usytuowana dość blisko punktu przyłożenia obciążenia. 